\title{
The Importance of Being Present: A Comparative Reading of Montaigne, Baudelaire, Canetti and Desnica
}

Abstract: Kalinić Snežana, The Importance of Being Present: A Comparative Reading of Montaigne, Baudelaire, Canetti and Desnica. "Poznańskie Studia Slawistyczne" 16. Poznań 2019. Publishing House of the Poznań Society for the Advancement of the Arts and Sciences, Adam Mickiewicz University, pp. 123-142. ISSN 2084-3011.

Even though they are different in many ways, Montaigne's essay "Of Experience", Baudelaire's poem "The Clock", Canetti's play The Numbered, and Desnica's novel The Springtimes of Ivan Galeb share a common trait. They all highlight the importance of now. This comparative study analyses various ways in which they depict the present time and demonstrate how the past and the future can disable mindful living in the present.

Keywords: time; life; death; Desnica; Montaigne; Canetti; Baudelaire; carpe diem

Michel de Montaigne, a famous French essayist, wine-grower and mayor of Bordeaux, lived from 1533 to 1592. Charles Baudelaire, a celebrated Parisian poet, essayist, and dandy, lived from 1821 to 1867. Elias Canetti, a Nobel Prize-winning novelist, essayist, and playwright of Bulgarian-Jewish origin, lived in Bulgaria, England, Austria, and Switzerland from 1905 to 1994. Vladan Desnica, an acclaimed Serbian and Croatian novelist, essayist, and poet, lived in Austria-Hungary and Yugoslavia from 1905 to 1967 . And yet, the writings of these celebrated authors share a common trait. Montaigne's essay Of Experience (De l'Expérience), Baudelaire's poem The Clock (L'Horloge), Canetti's play The Numbered (Die Befristeten), and Desnica's novel The Springtimes of Ivan Galeb (Proljeća Ivana Galeba) advise us to make the most of the "gift of "today" (Grimm, 1963, 317). They all demonstrate how the knowledge of the future and remembrance of the past can prevent us from "plucking the day" or make 
our day blossom. This comparative study analyses various ways in which Montaigne, Baudelaire, Canetti, and Desnica highlight mindfulness of the present, depict the interplay of the past, the present, and the future, and evoke the carpe diem tradition.

Many writers were influenced by Montaigne's Essays, but it was Flaubert who first realized that they should be read in particular way; not "for amusement", as children usually read, nor for education, "as the ambitious" tend to read, but "in order to live" (Bakewell, 2010, 11). Flaubert's witty remark inspired Sarah Bakewell to publish a book entitled How to Live: Or a life of Montaigne in One Question and Twenty Attempts at an Answer. The title of her book echoes Flaubert's remark and implies that Montaigne's essays address many issues, but attempt to answer a single major question: how to live. More importantly, the title evokes Montaigne's essay "Of Experience", where he claims that the most important "science" "is to know how to live this life" (Montaigne, 1952, 539-540). Bakewell claims that Montaigne offered as many as twenty attempts at an answer to such a question. She, however, fails to notice that half of his attempts are related to the same advice - be mindful of the present. Advices such as "Don't worry about death", "Wake up from the sleep of habit", "Pay attention", "See the world", "Do something no one has done before", "Let life be its own answer" (Bakewell, 2010, 1-310), seem to be related to completely different aspects of human life, but are, in fact, interconnected variations on an age-old answer to the how to live question: live in the present and make the most of the time you are given.

Of course, Montaigne was "not the first to attempt" such a way of life; that was one of the "rules recommended by the classical philosophers": "Life is what happens while you're making other plans, they said; so philosophy must guide your attention repeatedly back to the place where it belongs - here" (Bakewell, 2010, 37). Montaigne tried to catch up with the rapid pace of life, so he wrote The Essays in order to "maintain a kind of naïve amazement at each instant of experience" (Bakewell, 2010, 37). His essays allowed him to extend the duration of fleeting moments of his existence by writing about them. They enabled him not only to "spy on himself from close up" and present himself "in full view" and "all in the open" 
(Bakewell, 2010, 170), but also to live in a long-lasting present and use it as a touchstone for his past and future experiences. The Essays helped him to describe himself not as an "essence", but as "a passing [...] from day to day, from minute to minute" (Montaigne, 1952, 388). He used them to keep reminding himself of the evanescence and importance of every single moment (Montaigne, 1952, 388).

A number of Montaigne's essays depict his struggles with the future and the past, both of which threatened to lead him away from the present. Essays such as "That to Study Philosophy is to Learn to Die" ("Que philosopher c'est apprendre à mourir") show that the future made him concerned, while the past made him melancholic. Montaigne's other essays reveal that he defined the present according to its own merits; he understood that various kinds of pleasure resulted from direct experience of the present, much more than from remembrance of the past or anticipation of the future. One of his most important essays, the one entitled "Of Experience", offers a detailed description of "tasting" pleasure and "ruminating upon it", and comments on the carpe diem tradition (Montaigne, 1952, 541). Written in Montaigne's old age as his final essay, "Of Experience" describes a number of experiences but is devoted to "graceful aging" - preserving the ability to appreciate and enjoy life in spite of bodily frailty and "imminence of death" (Skenazi, 2013, 151). It shows that "old age, far more than youth, is the time of carpe diem" (Skenazi, 2013, 151-152). In his final essay, Montaigne quotes Seneca's warning against the foolish waste of life and Horace's carpe diem ode which advises us not to "worry about what lies ahead"" (Skenazi, 2013, 152). He himself claims that mortals should not "pass over the present" "to give themselves up to hope" (Montaigne, 1952, 541). Moreover, he urges his readers to make the most of every single experience. Montaigne describes his everyday activities and explains how he tries to be mindful of them or of himself performing them:

When I dance, I dance; when I sleep, I sleep. Nay, when I walk alone in a beautiful orchard, if my thoughts are some part of the time taken up with foreign occurrences, I some part of the time call them back again to my walk, to the orchard, to the sweetness of the solitude, and to myself (Montaigne, 1952, 538).

Statements such as these reveal Montaigne's attempts to be fully aware of all kinds of experiences. He strived to achieve "mindfulness" - "mindful 
attention" to life itself and "full awareness of the world as it is" (Bakewell, $2010,111)$ - in order to escape the force of habit and gain the pure essence of the present moment. His "When I dance, I dance; when I sleep, I sleep" tautology affirms his focus on hic et nunc and his coincidence with himself (Compagnon, 1988, 845). In addition, it reveals that he attempted much more than to be aware of his conscious experiences; he also tried to "sensibly relish and taste" his sleep: "To the end that even sleep itself should not so stupidly escape from me, I have formerly caused myself to be disturbed in my sleep, so that I might the better and more sensibly relish and taste it" (Montaigne, 1952, 541). He developed a keen interest in the "art required to sort and understand" his dreams, and, even in his old age, yearned for knowledge and experience (Montaigne, 1952, 533). Walking, dancing, sleeping, and dreaming are just a few of many different experiences which are discussed in his final essay. But only one of them is discussed repeatedly and in length - the experience of pleasure. Namely, Montaigne claims that pleasure is not "a brutish quality, unworthy to be tasted by a wise man", but an experience one should "study, taste, and ruminate upon" (Montaigne, 1952, 541). Pleasure plays a crucial part in resisting the destructive force of time. It does so even more in our old age: "we old fellows especially [...] let us take hold of the present"; "let us take the first opportune time of eating, and leave to almanac makers hopes and prognostics. The utmost fruit of my health is pleasure" (Montaigne, 1952, 536).

In addition to keeping us healthy and satisfied, pleasure compensates for the finitude and imperfections of our mortal lives. Elderly Montaigne reveals how he makes the most of the short time he has left in life by extending its "weight" and stopping "the promptitude of its flight": "I will stop the promptitude of its flight by the promptitude of my grasp; and by the vigour of using it compensate the speed of its running away" (Montaigne, 1952, 541). "Intellectually sensible, and sensibly intellectual", Montaigne doesn't simply take pleasure in something, but delights in it: "I ponder with myself of content; I do not skim over, but sound it" (Montaigne, 1952, 538). In addition, he admits to having "a special nomenclature" of his own for running "over the ill" and settling "upon the good": “I 'pass away time,' when it is ill and uneasy, but when 'tis good I do not pass it away: 'I taste it over again and stick to it"' (Montaigne, 1952, 540). 
As a result, he enjoys life "double to what others do": "I enjoy it double to what others do; for the measure of its fruition depends upon the more or less of our application to it" (Montaigne, 1952, 541).

Furthermore, Montaigne admits that he receives all the pleasures "a little too warmly and kindly" (Montaigne, 1952, 538). He portrays himself as a greedy eater: "I often bite my tongue, and sometimes my fingers, in my haste" (Montaigne, 1952, 537). In addition, he states that "pleasure is one of the chiefest kinds of profit" (Montaigne, 1952, 529). Suchlike confessions and statements associate Montaigne's final essay to carpe diem tradition even more than his allusions to Horace's famous ode. However, "Of Experience" goes a step further, and looks into the interplay of pleasure and pain. Montaigne ponders over proper ways of combining various sorts of pleasure so that there would be no "envy" among them (Montaigne, 1952, 537). Mismatched, our pleasures could "cross and hinder one another", and disturb us in our "fundamental" human occupation - living and enjoying out lives (Montaigne, 1952, 539). Hence, Montaigne advises caution and reminds us that life itself is "the greatest work of all" (Montaigne, 1952, 539). All our other experiences, including the experience of pleasure, are "but little appendices and props" for that "fundamental" activity: "That is not only the fundamental, but the most illustrious of all your occupations. [...] Have you known how to meditate and manage your life, you have performed the greatest work of all" (Montaigne, 1952, 539).

The "work" of living as "the greatest work of all" exceeds all other human occupations, even the most dignified ones: "The great and glorious masterpiece of man is to know how to live to purpose; all other things, to reign, to lay up treasure, to build, are, at most, but little appendices and props" (Montaigne, 1952, 539). Wise men "learn to suffer" what they cannot evade, accommodate their lives to their human nature, and remain "loyal" to their mortal selves: "We must patiently suffer the laws of our condition; we are born to grow old, to grow weak, and to be sick, in despite of all medicine" (Montaigne, 1952, 528-529).

With suchlike advices, elderly Montaigne connects aging both to the carpe diem approach to life and memento mori approach to illness and death. A large part of his final essay explains how illness faces humans with death and "skilfully and gently" puts them "out of concern with life" (Montaigne, 1952, 530). Yet, he also explains how he himself cultivates 
his life in spite of illness: "For my part then, I love life, and cultivate it, such as it has pleased God to bestow it upon us" (Montaigne, 1952, 541). Montaigne attempts to achieve the Stoics' amor fati, and to excel in refusing futile attempts to change the unchangeable, because when men "escape from being men", "they transform themselves into beasts", not angels (Montaigne, 1952, 542). He thinks that even the most powerful men should acknowledge their human limitations and come to terms with mortality. Paradoxically, the most mortal trait of Alexander the Great was his belief in his immortality: "I find nothing so [...] mortal in the life of Alexander, as his fancies about his immortalisation" (Montaigne, 1952, 543).

As a result, "Of Experience" ends with a joyful praise of mortal lives of humans and human lives of mortals. Such a glorification, written at the very end of Montaigne's Essays, can be seen as a powerful concluding wisdom "of Montaigne's definitive philosophy" (La Charité, 1970, 31). Nevertheless, one should remain cautious because of Montaigne's sceptical way of reasoning. Antoine Compagnon rightfully draws attention to the irony of Montaigne's writings, and questions the authenticity of the carpe diem message of his final essay. Compagnon notes that "Of Experience" contains contradictions and other traces of scepticism. Even though its Epicurean tone sounds like an adamant affirmation of the seizure of the present moment, Montaigne's final essay also implies that such a seizure is attained very rarely or merely partially (Compagnon, 1988, 841). Namely, although his "When I dance, I dance; when I sleep, I sleep" tautology affirms his ability to remain focused on hic et nunc, his description of his daily walks reveals that he often failed to enjoy suchlike experiences and managed to "seize the day" only after the fact; his thoughts were "some part of the time taken up with foreign occurrences" in spite of his efforts to remain focused on the walk itself or on himself walking (Montaigne, 1952, 538). Thus, "Of Experience" attests that Montaigne sometimes failed to seize the moment and that he merely attempted to persuade his mind and body to collaborate so that he could "grasp the fullness of the present" (Compagnon, 1988, 848; Skenazi, 2013, 152). Furthermore, his final essay reveals that he was convinced that enjoyment was much more a "divine perfection" than a human skill (Montaigne, 1952, 543). As a result, the Epicurean tone of Montaigne's last essay could be a mere trickery of procrastination because the present moment seems to be unattainable 
(Compagnon, 1988, 843, 846). Hence, Compagnon ends his paper about Montaigne in a Montaigne-like manner - with a suspensive conclusion (Compagnon, 1988, 848).

In addition, Compagnon finds that "Of Experience" contradicts another Montaigne's essay which also discusses the seizure of the present moment - "Apology for Raimond Sebond" (De L'Apologie de Raimond Sebond). In that extensive essay, Montaigne questions the presence of the present (Compagnon, 1988, 839). He relies on all the authorities of relativism, and refers to the Stoic claim that "there is no time present, and that what we call Present is nothing but the juncture and meeting of the future and the past" (Montaigne, 1952, 293). Consequently, Montaigne's "Apology for Raimond Sebond" doubts the existence of the present, while "Of Experience" offers something completely different - an adamant appraisal of living in the present. Nevertheless, "Of Experience" also seems to doubt the achievability of such a goal. Even in his final essay, Montaigne maintains that time flows without drawing our attention to the constancy and swiftness of its flow. In so doing, he connects "Of Experience" to another one of his famous essays, the one entitled "Of Repentance" (Du Repentir), where he presents himself as a creature subject to constant change in time, and notes that "the world eternally turns round" and that "constancy itself is no other but a slower and more languishing motion" (Montaigne, 1952, 388). In the same vein, "Of Experience" states that "our life is nothing but movement". Montaigne's final essay also reveals that its author is "slow in everything" (Montaigne, 1952, 532), and that time escapes him, just like all of us, in spite of all his efforts to seize the moment.

There are no reliable reminders of the passage of time; there is only its inevitable outcome. As a result, mortals are often deprived of the only dimension of time which always seems to be at hand - the present. But the wisest ones are at least able to recognize the problem. And the problem, according to Montaigne, is in the absence of a proper reminder - not of the past - but of the present.

Within the poetic vision of Charles Baudelaire, such a reminder, however, does exist, and even has a name: "The Clock". It is the title of the last poem of the "Spleen et Idéal" section of Baudelaire's Flowers of Evil (Les 
Fleurs $d u \mathrm{Mal}$ ). The ticking of a clock is the reminder which keeps reminding us of our mortality. Whenever we forget about the present, the Clock becomes a threatening god, who reminds us to live while we still can:

Horloge, dieu sinistre, effrayant, impassible,

Dont le doigt nous menace et nous dit: "Souviens-toi!"

Les vibrantes Douleurs dans ton coeur plein d'effroi

Se planteront bientôt comme dans une cible;

(Baudelaire, 1972, 120).

(The Clock, calm evil god, that makes us shiver,

With threatening finger warns us each apart:

"Remember!" Soon the vibrant woes will quiver,

Like arrows in a target, in your heart.

[Baudelaire, 1955, 100]).

We, however, fail to listen to the ticking of this "evil god" (Baudelaire, 1955, 100). For us, the ticking of a clock is an irrelevant quotidian sound, usually left unnoticed because of our various daily activities: "The cycle of clock-time, with its regularity, fragmentation, and duration, is a phenomenon of everyday life in urban modernity" (Russell, 2013, 245). Baudelaire, nevertheless, devotes the final poem of the first section of his Flowers of Evil to that persevering sound of the clock, which acts as a constant reminder of the present. Moreover, he uses the calm but steadfast sound of its ticking as a metaphor for the present time - the only dimension of time which is present always, but noticed very rarely. Even though we are inside the present all the time, it is inside us only once in a while - only in the moments when we are aware of it as the only temporal dimension which allows us direct consummation of time through acting.

Unlike most of us, Baudelaire does listen to the clock, and hears it warning us not to forget the present. The opening lines of his poem introduce the Clock as a terrifying deity, while the rest of the poem allows the Clock to speak for itself and to remind us to enjoy each moment of our short lives before it takes flight. Baudelaire's poem counterpoises Time to Pleasure by depicting Time as an unbreakable foe, which destroys the fleeting delights of Pleasure. In so doing, "The Clock" evokes Horace's carpe diem ode, where time is "an unbroken entity" which "snatches away all things eventually" (Grimm, 1963, 316-317). The mortals are advised to take pleasure 
in something, and thereby " "snatch away' something from time" (Grimm, 1963, 317). The carpe diem motif is also evoked by the number of verses which constitute "The Clock"; its 24 verses obviously correspond to the number of hours which constitute a day (Jackson, 1984, 447).

The third quatrain of "The Clock" depicts the fleetingness of the present, which rushes into the future, while itself becoming the past. Always lurking behind, the past refuses to disappear. Instead, it chases the present and "returns in uncanny ways to haunt" it (Baker, 2006, 1194). The haunting past prevents us from enjoying the present. The Now declares itself to be the Nevermore which has already passed away. Such a frightening message of the Clock is repeated three thousand six hundred times an hour:

\footnotetext{
Trois mille six cents fois par heure, la Seconde

Chuchote: Souviens-toi! — Rapide, avec sa voix

D'insecte, Maintenant dit: Je suis Autrefois,

Et j'ai pompé ta vie avec ma trompe immonde!

(Baudelaire, 1972, 120).
}

(Three thousand times and more, each hour, the second

Whispers 'Remember!' Like an insect shrill

The present chirps, 'With Nevermore I'm reckoned,

I've pumped your lifeblood with my loathsome bill'.

[Baudelaire, 1955, 100]).

Baudelaire describes the present as if it were equated with the past. As a result, the act of remembrance - a phenomenon usually related to the past - is related to the present in Baudelaire's poem. Mortals need to be reminded that the time they are given should be spent now, "whether in work or pleasure" (Baker, 2006, 1199). Otherwise, their short lives become "idle, meaningless succession" which leads to death (Baker, 2006, 1204). As a result, Baudelaire's Souvines-toi imperative is not only a call for urgent enjoyment of life; it is also a reminder of the passage of time and death. It is related both to the carpe diem motif and to the memento mori tradition (Jackson, 1984, 446). Baudelaire's Clock is a sinister deity of time, which flaunts its immortality in order to remind us that we ourselves are not immortal.

Besides immortality, another defining attribute of Baudelaire's timeassociated deity is its universality. The Clock's ticking sound is universally understood. Since aging is a world-wide web all of us are caught 
in, the Clock speaks all the languages. Baudelaire, however, singles out only three of them - English, French, and Latin: "Remember! Souviens-toi! prodigue! Esto memor!" (Baudelaire, 1972, 120). In order to highlight the Clock's threatening message, Baudelaire repeats Souviens-toi imperative five times in French, once in English, and once in Latin (Jackson, 1984, 447). In addition to creating a sense of urgency, those repetitions mirror the regularity of the Clock's ticking sound. The same effect is created by metrically aligned repetitions of the syllable $o i$ : "souviens-toi - c'est la loidécrôt - souviens-toi - soif” (Jackson, 1984, 447). The constant decrease of time left to enjoy life induces continual sense of thirst in a mortal. His or her life is a gamble with Time - the mighty adversary who wins every round. As a result, the mortal's life is a game lost from the beginning.

With such a description of Time, "The Clock" alludes to "the boredom of the urban time", which Benjamin defines as "splenetic time" (Baker, 2006, 1201). Appropriately, "The Clock" is the concluding poem of the "Spleen et Idéal" section of Flowers of Evil. Its main subject - the foolish waste of present time - is one of the gravest consequences of succumbing to spleen - a highly destructive phenomenon which connects boredom to melancholy and numbness. Spleen is the supreme destructive force, all the more devastating since it seems to cause nothing, while it actually paralyzes our body and mind, by depriving us of all emotional and intellectual contents. As such, spleen undermines Baudelaire's "artificial paradises", all of which expose "the sham utopia": "Baudelaire's phrase 'artificial paradises' $[. .$.$] is one of the 19^{\text {th }}$ century's most memorable phrases for the sham utopia [...] promised by commodity culture" (Baker, 2006, 1204). By depicting "the profane time of the city" as "idle, meaningless succession", "The Clock" unveils the "sham utopia" and warns us against "the illusionmaking capacity of urban existence" (Baker, 2006, 1204). As a result, "The Clock" is not only an ideal conclusion of the first section of The Flowers of Evil, but also an appropriate introduction to the second one; it announces various ways in which "Tableaux parisiens" unmask "the illusion-making capacity" of the $19^{\text {th }}$ century Paris.

$*$

A number of illusions are unmasked in another literary master-piece. Published almost a hundred years after The Flowers of Evil, Elias Canetti's 
play The Numbered also unmasks a "sham utopia" of sorts. It is a play, singled out by Canetti himself as his most significant literary work, ${ }^{1}$ which unveils "the illusion-making capacity" of "a nameless future society" that has allegedly "abolished the fear of death by claiming to control the moment of its occurrence" (Baker, 2006, 1204; Willingham, 1992, 71). The members of that society are called the numbered because they are defined by the numbers which reveal their life expectancy and announce the precise moment of their future death:

At birth, all children receive lockets containing their dates of birth and dates of death. Only an official known as the Locketeer can open this locket, and it is he who christens each child according to the age he will be when his 'moment' comes - Forty-five, Sixty, Eighty-one, and so on. When individuals die, the Locketeer opens their lockets and verifies that the dates are correct. Everyone knows by the person's name how old he or she will be when the 'moment' arrives, but only the individual knows his or her own birth date, and thus how many years he or she has left (Willingham, 1992, 71).

As a result, The Numbered explore the possibility that the defining moment of someone's life is not the moment of his or her most intense life experience, but the moment of his or her death. Canetti creates a world in which the knowledge of the future deeply affects not only personal identities, but also human relations. The social hierarchy of such a world is determined in a peculiar way: not by virtue, wealth or noble origin of the individuals, but by the number of their life years. The high-numbered are appreciated more than the low-numbered, who will die young, and miss out on some of the most rewarding life experiences.

A few exceptions are noted. A high-numbered man in search of a suitable life partner does not aim at marrying a high-numbered woman. Instead, he aims to get engaged several times, with a number of low-numbered women, because they are less demanding and more adventurous. On the other hand, a low-numbered woman searches for a life partner with a life span equal to hers because she wants a reliable man - the one who is prompted by his short life to be fast-thinking and hard-working.

${ }^{1}$ Canetti claimed that The Numbered were more significant than his better-known works. When he was asked whether his most important work was Auto-da-Fé or Crowds and Power, he replied that it was neither one of the two, but his less known play The Numbered (Medenica, 2015, 27). 
Canetti's play also explores the ways in which the knowledge of the future affects human identity, integrity, and sense of freedom. The foretold future was supposed to set the numbered free, if not from death itself, then from the fear of it. In addition, it was supposed to liberate them from their own unrealistic dreams and unrealizable plans, and allow them to "seize the day" and lead a fulfilling life. The Locketeer proudly claims that a certain number of certain years is more worthy than any uncertain number of uncertain ones (Kaneti, 2015, 237), even though the established social order failed to reach the utopian goal. Instead of erasing the fear of death and unrealistic hopes, it deprived the numbered of a satisfactory life in the present. A man is desperate because he knows that he lacks time to complete his life work (Kaneti, 2015, 245-247). A woman is bothered by the possibility that her life partner might outlive her or that she might outlive him. An ill-mannered boy is allowed to misbehave and neglect his education simply because he will die at the age of ten (Kaneti, 2015, 243-245). The boy's mischiefs, however, fail to compensate him for the loss of his future. Instead, they reveal that youth is a fluid phenomenon. Even though the ten-year-old boy behaves in a very childish manner, he is deprived of far-reaching hopes and therefore older than a fully-grown man with many years ahead of him.

Youth is not the only phenomenon which is redefined in such living conditions; human feelings are transformed as well. A mother is not grief stricken over her child's death simply because she knew from the start that she would outlive him (Kaneti, 2015, 250). The knowledge of the future causes two young gentlemen to start suffering from a kind of boredom not unlike Baudelaire's spleen, because of which each experience they acquire seems to be lacking content (Kaneti, 2015, 251). As a result, the two gentlemen begin to wish for the risk and become ready to trade their certain future for an uncertain present.

Some of the numbered start to experience their world as dystopian. Namely, the world of The Numbered seems to be utopian in the Prologue alone. At the beginning of the play, the numbered do enjoy the certainty of their numbered lives. Two men admit that they wouldn't be able to make any plans without knowing the time of their death because the suspense would be an unbearable burden. In so doing, they confirm their belief in the "myth of social advancement over past ages, when people lived in 
fear of death" (Willingham, 1992, 71). However, the rest of Canetti's play shows that the knowledge of the future does not gratify the numbered but harms them instead. It loosens their family ties, destroys relationships and friendships, and decreases their productivity. As a result, Canetti's "sham utopia" unveils all the phenomena which become limited due to a limited future. Limited future limits the present. Instead of expanding it by transforming the upcoming events into an immanent certainty, announced future undermines the main feature of the present - its openness towards the other two dimensions of time. The world of The Numbered becomes dystopian for various reasons, but mostly because it disturbs the very core of utopian vision: "seeing the world as unfixed and unfinished - as open" (McManus, 2005, 15). Inside Canetti's fictional world, the usual time flow is disturbed: the foretold future is already present, while the present itself is out of joint. The present stops functioning as the bridge between the future and the past, and fails to enable the numbered to understand the past, experience the present, and prepare themselves for the future. As a result, the knowledge of the time of death does set them free. However, it liberates them from suspense, not from death. The anticipated future deprives them of authentic excitement and fulfilling life in the present.

By presenting the society of the numbered, Canetti alludes to Horace's carpe diem ode. His play affirms that "it is wrong, impious" "to seek to know the future" (Grimm, 1963, 314). The ones who attempt to anticipate it end up being "doubly foolish, having lost today in a vain attempt to know tomorrow" (Grimm, 1963, 317). In addition, Canetti's play raises several important questions. Is the future without suspense an authentic one? Can it be serene and soothing? Must it be disturbing and frightening? Who experiences life to the fullest: the one rushing through his short life or the one relishing in his long one?

The Numbered de monstrate that life without suspense stops being exciting and becomes episodic instead. The play itself has an episodic structure; its plot consists of several scenes with a number of characters in various life situations. A single character, a man named Fifty, stands out, appears in most of the scenes, and connects different episodes of The Numbered. He doubts the honesty of the Locketeer, suspects that the announced future is false, and rebels against such a world order. He finally wins the freedom which consists in nobody knowing the real time of his 
or her death. Fifty manages to convince the others that they have been deceived but fails to make them realize that false knowledge is worse than authentic ignorance. They begin to substitute one utopia with another (Medenica, 2015, 29) by searching for the ways of making the uncertainties of unknown future appear appealing and engaging. One of them, for example, starts to claim that there is justice in the fact that people are equal not only in respect of their mortality, but also in respect of their ignorance about the time of death. Instead of substituting their false knowledge with authentic ignorance, some of the numbered rush into another "sham utopia" - the one based on the belief in universal immortality. As a result, authentic life in the present escapes them at the end of Canetti's play just as it did at its beginning. The Numbered imply that there is no escape from illusions turning into delusions, or from utopias turning into dystopias, whenever human mortality is concerned.

$*$

A much less pessimistic insight into human mortality, and a sober understanding of human vitality, can be found in The Springtimes of Ivan Galeb - Vladan Desnica's novel which was published in 1957, a year after the Oxford premiere of Canetti's play. The Springtimes of Ivan Galeb offer a sound representation of death and its interplay with "the springtimes" joyful moments of reawakening in a mortal's life. The hero and narrator of Desnica's novel, Ivan Galeb, is an elderly violinist who ponders over life, death, God, music, theatre, and truth, while facing death in a hospital bed. His diary helps him to come to peace with a danse macabre realization that the only authentic democracy in human life is "democracy of death" (Десница, 1990, 234). ${ }^{2}$ Galeb learns to accept death as the most important content of life. He claims that mortality is "the only eternal presence" inside humans (Десница, 1990, 79). Death grows inside them, in the same pace as they themselves do, and maintains good relations with life during their childhood. Later on, death grows in strength and overpowers life in all living things. Moreover, it gains power to affect the inanimate things, such as old family portraits and hair-locks, which also pass away eventually. Yet, Galeb continues to experience "the springtimes" as counterparts

\footnotetext{
${ }^{2}$ All the translations of quotes from Desnica's novel are mine.
} 
of death, and appreciates them as dashes of immortality, which represent the fragile but persistent endurance of life in spite of the omnipresence of death.

In addition to being an insightful novel about the interplay of life and death, Desnica's novel is also a Künstlerroman - a novel which tells the story of an artist's childhood, maturity, and old age (Поповић, 2007, 176-177). Furthermore, it is also a Zeitroman - a novel focused on various aspects of time. As an educated and sensitive musician, Galeb offers deep insights into the nature and passage of time. He explains that it gives weight to all the events of life. Once a mortal abandons temporal perspective, his or her life experiences start to be perceived as "equally important or unimportant" (Десница, 1990, 337). Two interconnected metaphors of a "landscape" and a "life-rug" (život-ćilim) depict the feeling a mortal gets once he outgrows himself, and allows all the days of his life to align themselves into a single plateau which resembles the greenery of a relaxing landscape. Deprived of before and after, his life stops to be perceived as good or bad, and starts to resemble a "life-rug" - pure "arabesque" of "almost painless thoughts" (Десница, 1990, 16, 337).

However, mortals abandon temporal perspective only once in a while. Usually, they experience each life situation as located in-between before and after. So does Ivan Galeb. Most of his thoughts flock around his past; his narrative is an existential résumé of the life he led before his hospital days. Particularly attached to childhood memories, Galeb considers them to be the most relevant part of life. In addition, he appreciates childhood as the only period in which a mortal is given the opportunity to try on the blue dress of immortality and experience life to the fullest (Десница, 1990, 55).

Even though Galeb's narrative is focused on his past, his thoughts gather around his present. And his present is marked by old age - lifeperiod in which human body is more fragile and utterly exposed to pitfalls of mortality. Galeb writes about his struggle with illness and solitude. Nonetheless, his old age is a period of serenity, poise, and meditation for him. He finds it to be completely deprived of narcissistic desires, pressing needs, and restless blood flow, which used to mark the "craving fevers" of his youth (Десница, 1990, 78). As a result, Galeb embraces the "mature, humble wisdom" of old age, and claims to be ready for death (Десница, 1990, 342). Fatigued, he feels at ease with the shortcomings of mortal life. 
However, he is not yet willing to pass away. Even as an ailing old man, Galeb never ceases to wish "for a sunset-proof today" (za nezalaznim danas) (Десница, 1990, 342). In spite of hospital predicaments, he experiences "panic feeling of time" (panično osjećanje vremena), and keeps in mind its "fleetingness" (bježuljivost), "pricey irreversibility" (skupu nepovratnost) and "terrifying once-onlyness" (stravičnu jednokratnost) (Десница, 1993, 71; 1990, 272). He makes notes in his diary on daily bases, and thereby practices a carpe diem approach to life which entails the appreciation of not only the delights and comforts, but also the hardships and discomforts of every single day. His diary is an art of being present and mindful of all the experiences, including the "bare sensation of existence" (Десница, 1990, 336). Even during the half-awake states after the surgical procedure, he attempts to be mindful of the reality continuum, and hopes that the "lasting itself" will last long enough to "convince" him in "the reality of the real" (Десница, 1990, 337). He learns to appreciate the presence itself and bare existence, deprived of volume or his own participation in it (Десница, 1990, 336).

As a result, Galeb comprehends the importance of being present much more than the mortals addressed by Baudelaire's Clock. Even in dire circumstances of post-surgical "eons of nothingness" (Десница, 1990, 332), he still clings to the present because his vitality is not damaged by illness. On the contrary, illness endows him with leisure time, which is necessary for writing. As a result, The Springtimes represent both the hardships and the delights of every single carpe diem (Стојановић, 2007, 151). While Baudelaire's poem calls for the appreciation of all the joys, Desnica's novel demonstrates the importance of being present in spite of illness and old age.

Instead of feeling desperate, Galeb writes about his present thoughts, relates them to his memories, and manages to overcome his fear of future death. He achieves such an accomplishment because he never allows the present to be subdued by the other two dimensions of time. Mindful of his past experiences, and in preparation for the ones which are yet to come, he never forgets to pay attention to the present. Even the narration of his life story reveals his mindfulness of the present; he constantly interrupts and neglects his past-oriented narrative thread, and notes one digression after another, because he feels that the essence is in those very "digressions" 
(Десница, 1990, 124). ${ }^{3}$ Such a narrative strategy pays more attention to narrator's present thoughts and feelings than to hero's past experiences, and makes the importance of being present not only a subject of Desnica's novel, but also an important part of its form.

In addition, Galeb's narrative strategy enables him to keep his memories alive without over-attaching himself to the past. Aware of the dangers of the haunting past, he rarely succumbs to incurable nostalgia. In chapters 63 and 64, he writes about returning to his hometown, where he searched in vain for a cure. Hoping to evoke the familiar voices of the past, he went to the locked room to which his nanny used to take him, but failed to find proper reminders of his childhood. Instead, he discovered boxes which were filled with family portraits and hair-locks, but utterly unable to evoke his memories. As a result, Galeb rejected them as dry witnesses of their own demise, and realized that inanimate objects pass away just like the animate ones. In addition, he was surprised to find that even the most vital part of his past, his imaginary friend Bućko, had also lost the power to evoke memories. Consequently, Galeb concluded that the world was over-burdened by the weight of the things past and decided to burn the lifeless memorabilia and transform them "from one form of nothingness into another" (Десница, 1990, 313). Such eradication of his past was supposed to prevent the stale air of yesterday to give birth to death and provide it with an appropriate nest for growth. Otherwise, the past could become so bloodthirsty that it could devour both the present and the future, just like "a starving bitch" eats "her cubs" (Десница, 1990, 314).

Exhausted by inherited burdens and the surplus of experiences, Galeb starts to perceive himself as a time-worn deity of time - "dying Chronos" - and leaves his hometown determined to liberate himself from the weight of past things and the perils of nostalgia (Десница, 1990, 314). Yearning for a fresh start, he starts to call forth a "new man", "free as a bastard", so that today could manage to "sprout up" from the "suffocating yesterday" (Десница, 1990, 313). As a result, Desnica's novel demonstrates how succumbing to nostalgia leads to the wrong conclusion that future belongs to the ones without the past. Fortunately, the other chapters of The

${ }^{3}$ Galeb dreams about writing a novel deprived of story lines, and made of "digressions" only (v. Вукићевић, 2007, 71-86). 
Springtimes opt for a much less destructive treatment of time. Galeb does not attempt to outrun his past, or to slow down the future, in order to appreciate the present. Rather, he reaches the "mature, humble wisdom" which appreciates all the dimensions of time (Десница, 1990, 342).

Yet, before acquiring such wisdom, Galeb needs to become aware that chasing the future can be as dangerous as the haunting past. He needs to realize that the urge for going forward could make a mortal rush through life, and miss out on some of the most rewarding experiences. Excessively concerned with what is yet to come, mortal neglects the opportunities which today has to offer, fails to enjoy the present, and wastes its delights on vain attempts to "consume the tomorrow's and the-day-after-tomorrow's portion of life today" (Десница, 1990, 342). Galeb admits that he used to have "time fever" and live his life in haste. However, long periods of idleness spent in the hospital bed made him realize the uselessness of haste and the folly of racing against time. He stopped feeling the urge for going forward, developed a need for slowing down, and recognized the moment of that shift as the beginning of his old age.

The end of Desnica's novel presents Ivan Galeb as a wise man who has managed to overcome his fear of death. He leaves the hospital, takes a walk, and enjoys each step he makes in a Montaigne-like manner. $\mathrm{He}$ cheerfully declines the colporteur's offer to give him the newspapers containing tomorrow's news, and makes a joke by asking him for the-dayafter-tomorrow's news. Instead of feeling the thirst for tomorrow, his final desire is the one for an everlasting - "sunset-proof" - today (Десница, 1990, 342). Such craving marks the beginning of another springtime in his life, which allows him to enjoy the Mediterranean sun in spite of the shadow of forthcoming death.

$*$

Montaigne's essay "Of Experience", Baudelaire's poem "The Clock", Canetti's play The Numbered and Desnica's novel The Springtimes of Ivan Galeb differ in many ways. They treat diverse subjects, correspond to different literary genres, and belong to different periods of literary history. And yet, they all highlight the importance of being present and evoke the carpe diem tradition. They demonstrate that living in the present is the necessary condition for a meaningful and authentic life, and depict the present 
in a similar way - as the only dimension of time which is always at hand, but hardly ever attained because of our various efforts to remember our past or anticipate our future.

Montaigne's essay "Of Experience" instructs the mortals how to be mindful and appreciative of all their experiences, even the most common ones, and how to triumph over time's relentless linear progression by graceful aging. Baudelaire gives the ticking Clock a voice of its own, warns the mortals against the dangers of the haunting past, and reminds them to enjoy every moment of their short lives. Instead of haunting past, menacing future is the focus of Canetti's play. The Numbered describe the perils of anticipation, demonstrate how limited future limits the present, and unveil the deceptions of a dystopian society which has allegedly overcome the fear of death. And Desnica demonstrates how to become aware of the past, mindful of the present, and prepared for the future, even in a hospital bed. As a result, Montaigne, Baudelaire, Canetti, and Desnica contribute to the carpe diem tradition and display various ways in which a mortal can assert his or "her own individuality in the face of a grim universe" (Grimm, 1963, 318). In spite of differences, they all offer us the same gift - the "gift of 'today"' (Grimm, 1963, 317).

\section{References}

Baker, J.M, Jr. (2006). Vacant Holidays: The Theological Remainder in Leopardi, Baudelaire, and Benjamin. "MLN" 121 (5), Comparative Literature Issue, Dec., pp. 1190-1219.

Bakewell, S. (2010). How to Live: Or a life of Montaigne in One Question and Twenty Attempts at an Answer. London: Other Press.

Baudelaire, C. (1972). Les Fleurs du Mal. Paris: Gallimard.

Baudelaire, C. (1955). The Flowers of Evil. Ed. M. and J. Mathews. Trans. by R. Campbell. New York: New Directions Books.

Compagnon, A. (1988). L'écriture de l'instant das les 'Essais'. "Revue d'Histoire littéraire de la France" 88 (5), Sept.-Oct., pp. 839-848.

Grimm, R.E. (1963). Horace's 'Carpe Diem' . "The Classical Journal” 58 (7), April, pp. 313-318.

Jackson, J.E. (1984). Baudelaire lecteur de Théofile Gautier les deux 'Horloges'. "Revue d'Histoire littéraire de la France" 84 (3). May-Jun., pp. 439-449.

La Charité, R.C. (1970). The Relationship of Judgement and Experience in the 'Essays' of Montaigne. "Studies in Philology" 67 (1), Jan., pp. 31-40. 
McManus, S. (2005). Fictive Theories: Towards a Deconstructive and Utopian Political Imagination. New York: Palgrave.

Medenica, I. (2015). Nazad ka velikim naracijama. In: Antologija savremene nemačke drame I. Prev. i prir. J. Kostić-Tomović et al. Beograd: Zepter Book World, pp. 1130.

Montaigne, M. de (1952). The Essays of Michel Eyquem de Montaigne. Trans. C. Cotton. Ed. by W. C. Hazlitt, Chicago - London - Toronto: Encyclopaedia Britnnica, Inc.

Kaneti, E. (2015). „Oročeni“. Antologija savremene nemačke drame I. Prev. i prir. J. Kostić-Tomović et al. Beograd: Zepter Book World, pp. 223-284.

Russell, C. (2013). Archival Cinephilia in the Clock. "Framework: Journal of Cinema and Media", 54 (2). Fall, pp. 243-258.

Skenazi, C. (2013). Aging Gracefully in the Renaissance: Stories of Later Life from Petrarch to Montaigne. Boston: Leiden.

Willingham, R. (1992). Dystopia Visions in the Plays of Elias Canetti."Science Fiction Studies" 19 (1). March, pp. 69-74.

Вукићевић, Д. (2007). Монолитност дела Владана Деснице, In: Книжевно дело Владана Десниие: зборник радова поводом 100-годишњиие рођења. Ур. Ј. Радуловић и Д. Иванић. Београд: Библиотека града Београда - Чигоја штампа, pp. 71-86.

Десница, В. (1990). Прољећа Ивана Галеба: игре прољећа и смрти. Београд - Нови Сад: Рад - Будућност.

Десница, В. (1993). Есеји, чланци, погледи. Београд: БИГЗ.

Поповић, Т. (2007). Свет који нестаје - Десница и Џојс, In: Къижевно дело Владана Деснице: зборник радова поводом 100-годишњище рођења. Ур. Ј. Радуловић и Д. Иванић. Београд: Библиотека града Београда - Чигоја штампа, pp. 175-206.

Стојановић. Д. (2007). Јас живота и јас смрти. In: Поверење у Богородииу. Београд: Досије, рр. 127-156. 